\title{
Atmospheric air plasma induces increased cell aggregation during the formation of Escherichia coli biofilms
}

\begin{tabular}{|r|l|}
\hline Journal: & Plasma Processes and Polymers \\
\hline Manuscript ID & ppap.201700212 \\
\hline Wiley - Manuscript type: & Full Paper \\
\hline Complete List of Authors: & $\begin{array}{l}\text { Cullen, Patrick; university of new south wales, chemical engineering } \\
\text { Kwandou, Goldina; university of new south wales, Chemical engineering } \\
\text { spicer, patrick } \\
\text { Prescott, Stuart } \\
\text { Mai-Prochnow, Anne; csiro }\end{array}$ \\
\hline Keywords: & \\
\hline
\end{tabular}

SCHOLARONE ${ }^{\text {m }}$

Manuscripts 

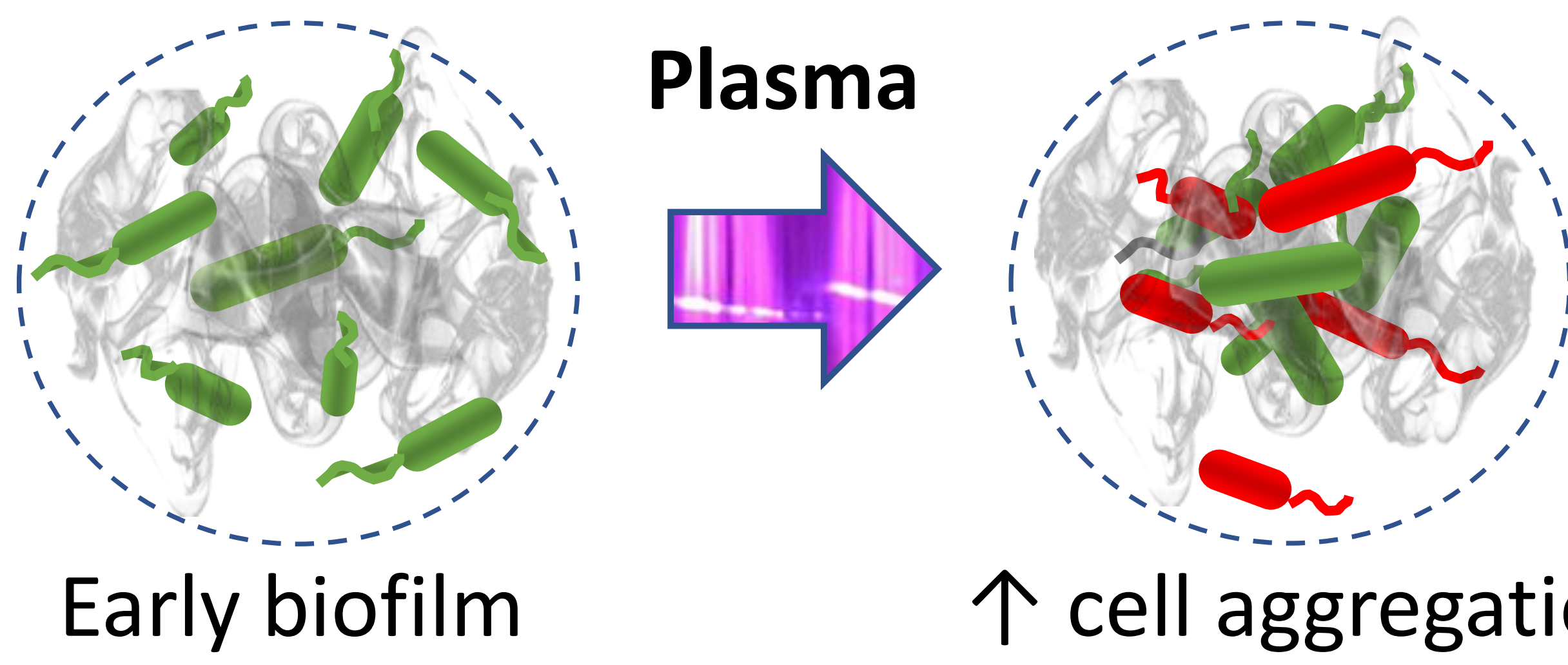

$\uparrow$ cell aggregation $\&$ death 


\section{Article type: Full Paper}

Atmospheric air plasma induces increased cell aggregation during the formation of Escherichia coli biofilms

Goldina Kwandou ${ }^{1}$, Anne Mai-Prochnow ${ }^{2}$, Stuart W. Prescott ${ }^{1}$, Patrick T. Spicer ${ }^{1} \&$ Patrick J. Cullen ${ }^{1,3 *}$

1 School of Chemical Engineering, UNSW, Sydney, 2052, Australia

Email: p.cullen@,unsw.edu.au

2 CSIRO Manufacturing, P.O. Box 218, Lindfield, NSW 2070, Australia

3 Department of Chemical and Environmental Engineering, University of Nottingham, UK.

Keywords: atmospheric plasma; biofilms; cell agglomeration 


\section{Abstract}

2 Atmospheric air plasma has previously been shown to be a novel and effective method for

3 biofilm eradication. Here we study the effects of plasma on both microbial inactivation and

4 induced structural modification for forming biofilms. New structures are created from 5 aggregates of extracellular polysaccharides and dead bacterial cells, forming a protective and

6 resilient matrix in which the remaining living cells grow and reproduce under proper growth

7 conditions. The new colonies are found to be more resilient in this state, reducing the efficacy

8 of subsequent plasma treatment. We verify that the observed effect is not caused by chemicals

9 produced by plasma reactive species, but instead by the physical processes of drying and 10 convection caused by the plasma discharge.

11 


\section{Introduction}

Biofilms are colonies of microorganisms surrounded by a complex fluid matrix made predominantly of extracellular polysaccharide polymers (EPS). The EPS provides a protective barrier for bacterial colonies in a biofilm, ${ }^{[1]}$ increasing the resistance of bacteria to chemical and antibiotic treatments and also reducing the efficacy of physical treatment. Biofilms can thus survive most conventional methods of eradicating more freely dispersed, or planktonic, bacteria $^{[2]}$. Biofilms can form on many surfaces, including the skin of fresh fruits and vegetables, industrial pipe surfaces, in between teeth, and on medical devices. ${ }^{[3,4]}$ Due to their widespread existence and resilience, biofilms are known to be the main cause of persistent bacterial infections in hospitals, ${ }^{[5]}$ contamination of foods in process environments, ${ }^{[6]}$ and reduced process cleaning efficiency in manufacturing. Biofilm physical and flow properties have recently been studied as a means of understanding molecular transport through the matrix and to better enable destruction. ${ }^{[7,8]}$ New approaches are being developed to more aggressively treat biofilms during formation, for example to interfere with the attachment of these bacteria to surfaces and disturb their structure. ${ }^{[9]}$

One novel treatment currently being investigated for this purpose is atmospheric plasma, which is essentially an ionized gas that is generated at ambient temperatures and under atmospheric conditions that allows treatment of sensitive biological matter ${ }^{[10,11]}$ Numerous recent studies have demonstrated the anti-microbial efficacy of atmospheric plasma for planktonic bacteria or cells embedded in biofilms. ${ }^{[12]}$ Plasma species are reported to be capable of penetrating into the biofilm structure. ${ }^{[13]}$ Plasma can inactivate biofilms with treatment times of less than 60 seconds $^{[14]}$ and cause a $5 \log$ reduction in biofilm viability, ${ }^{[15]}$ while longer treatments can decrease viable cells to undetected levels. ${ }^{[15-17]}$ This ability of plasma to inactivate bacteria is thought to be an effect of its production of short- and longlived reactive species ${ }^{[18]}$ such as ozone and other radicals. ${ }^{[19]}$ Long-lived species have been 

shown to be effective to treat Escherichia coli suspensions even after a 7-day period, following plasma liquid generation. ${ }^{[20]}$

Apart from its ability to inactivate bacteria in a biofilm, atmospheric air plasma has been shown to change the overall biofilm structure by disrupting and degrading the EPS biofilm components. ${ }^{[21]}$ For example, separation of initially aggregated bacteria has been observed during EPS degradation due to plasma treatment. ${ }^{[22]}$ Plasma-induced EPS degradation causes a decrease in biofilm thickness ${ }^{[21,23]}$ and volume ${ }^{[21]}$ as well as an increase in its roughness and porosity. ${ }^{[21]}$ Plasma-treated biofilms are also known to have reduced adhesion to surfaces. ${ }^{[23 \text {, }}$ 24]

In model systems, monolayers of surface-deposited Listeria innocua responded to plasma treatment by forming cell aggregates of damaged cells, into which viable cells were then moved, affecting plasma inactivation kinetics. ${ }^{[28]}$ Bayliss et al ${ }^{[28]}$ suggested such sheltering of cells extends the treatment time needed for bacterial inactivation and is driven by plasma gas flow-induced drying and the resultant fluid shear stresses. Although the work was carried out on a manually-deposited layer of cells, it likely has relevance for more developed biofilm community environments as well. This work examines the effects of short duration plasma treatments on young biofilm structures and how modification of those structures affects bacterial resilience to subsequent plasma treatments.

\section{Experimental Section}

\subsection{Preparation of biofilm sample}

Single E. coli MG1655 (CSIRO Food Research Ryde Bacteriology Culture Collection) colonies were inoculated in nutrient broth $\left(1 \mathrm{~g} \mathrm{~L}^{1}\right.$ 'Lab-Lemco' powder, $2 \mathrm{~g} \mathrm{~L}^{-1} 170$ yeast extract, $5 \mathrm{~g} \mathrm{~L}^{-1}$ peptone, $5 \mathrm{~g} \mathrm{~L}^{-1}$ sodium chloride, $\mathrm{pH}$ 7.4; Oxoid, Adelaide, Australia) and 
grown in a shaking incubator (Bioline Global, South Australia) at $37^{\circ} \mathrm{C}$ and $100 \mathrm{rpm}$ for 12 to 15 hours. The cultures contained approximately $10^{9} \mathrm{CFU} / \mathrm{mL}$ which was diluted to $10^{7}$ $\mathrm{CFU} / \mathrm{mL}$. From this diluted culture, $2 \mathrm{~mL}$ samples were transferred to a FluoroDish ${ }^{\mathrm{TM}}$ cell culture dish (World Precision Instruments). These dishes were incubated at $37^{\circ} \mathrm{C}$ to allow biofilm formation. After 24 hours, the medium was exchanged for fresh medium. The biofilms were grown for a period of 48 hours total for time-dependent and liquid coverage experiments or 24,48 , and $72 \mathrm{~h}$ for cell regrowth and multiple-treatment studies, after which the medium was removed and the biofilm washed twice with phosphate buffered saline (PBS) prior to treatment and analysis. Details of the regrowth studies are provided in section 2.3.

\subsection{Plasma setup}

The power supply used to drive the plasma discharge was an HV half bridge resonant inverter circuit (PVM2000, Information Unlimited, New Hampshire, USA). The power source has a maximum output voltage of $50 \mathrm{kV}$ with a variable frequency of $20 \mathrm{kHz}$ to $100 \mathrm{kHz}$, depending on the plasma load capacitance. The plasma setup consists of a FluoroDish ${ }^{\mathrm{TM}}$ used to grow the biofilm (see section 2.1) that is placed in between the electrodes of the Dielectric Barrier Discharge, or DBD, consisting of a $2 \mathrm{~mm}$ thick poly(methyl methacrylate) dielectric and a top electrode that is partially recessed within the imaging dish to reduce the discharge gap to $6 \mathrm{~mm}$ (Figure 1a). The discharges were induced in open atmospheric air conditions.

\subsection{Plasma-biofilm treatment conditions}

\subsubsection{Direct treatment}

The growing biofilms were exposed to direct plasma treatment, Figure 1a, after $24 \mathrm{~h}$ or $48 \mathrm{~h}$ of growth, while only biofilms aged $48 \mathrm{~h}$ were exposed to plasma-activated liquid (see section 2.3.2 below, Figure 1b). Plasma treatment was performed at $6 \mathrm{kV}$ and $\sim 60 \mathrm{kHz}$. The optical 
emission spectra, OES, for the discharge were mainly in the UV region, the OES are not included, the reader is referred to Lu et $a l^{[25]}$ for characterisation of discharges with this power source. The DBD design incorporating the dish used to grow the biofilm allows for noninvasive sample preparation, which is critical for later imaging of a biofilm's structure. The design also offers the added benefit of a relatively controlled discharge in terms of spatial homogeneity and treatment time when compared to plasma jets. Precise control of treatment time $(\sim 1 \mathrm{~s})$ allows the effects of short plasma treatment times on biofilm behaviour to be investigated.

For time-dependent studies, biofilms aged $48 \mathrm{~h}$ were exposed to direct plasma for times ranging from 0 to $60 \mathrm{~s}$. The biofilm was kept wet by adding $200 \mu \mathrm{L}$ of PBS into the dish. For liquid coverage studies, different amounts of PBS were added to the cell culture dish, from $200 \mu \mathrm{L}$ to $1000 \mu \mathrm{L}$, and biofilms aged $48 \mathrm{~h}$ were used. In the regrowth study, biofilms aged $24 \mathrm{~h}$ and $48 \mathrm{~h}$ were used and exposed to plasma for $30 \mathrm{~s}$. On each day, biofilms were compared to untreated controls (Table 1). After exposure to plasma, biofilms were incubated again with fresh nutrient broth at $37^{\circ} \mathrm{C}$. All nutrients were changed every $24 \mathrm{~h}$ until the final day $(72 \mathrm{~h})$.

\subsubsection{Indirect (liquid) treatment}

Plasma-treated liquid was generated by treating $1 \mathrm{~mL}$ of PBS in the same setup as direct treatment, as indicated in Figure 1B. After treatment, $200 \mu \mathrm{L}$ of the liquid was removed from the dish and transferred to another dish containing the biofilm, and subsequently incubated for 1 hour prior to imaging. Commercial hydrogen peroxide (Chem-Supply Pty Ltd, South Australia, Australia) was employed for comparison to the plasma-treated liquid via addition to PBS. Similarly, $200 \mu \mathrm{L}$ of these peroxide-PBS solutions were also incubated for 1 hour with the biofilm prior to imaging. 


\section{$114 \quad 2.4$ Confocal Laser Scanning Microscopy (CLSM)}

115 Before imaging, the biofilm was dyed with Live/Dead BacLight ${ }^{\mathrm{TM}}$ Bacterial Viability Kits

116 (Thermo Fisher Scientific, Victoria, Australia), which contains SYTO9 and Propidium Iodide

117 (PI), following supplier's instructions. The dishes were then incubated in the dark for about

11815 mins before imaging. Biofilm imaging was performed on a Leica TCS SP5 STED inverted

119 confocal microscope with oil objective $63 \times$, NA 1.4. The lasers used for imaging were at 488 $120 \mathrm{~nm}$ for SYTO9 and $498 \mathrm{~nm}$ for PI.

121

122

124

125

126

\subsection{Image analysis}

All images were analysed using Image-J. ${ }^{[26]}$ Green and red channels from CLSM data were separated and then analysed individually to calculate biofilm coverage area. From the literature it is known the approximate size of one $E$. coli cell is $1 \mu \mathrm{m} \times 3 \mu \mathrm{m} .{ }^{[27]}$ Assuming the cells are perfectly oval, the area of one $E$. coli cell is $2.35 \mu^{2}$. Hence, any number that is less than this value is disregarded in the calculation. The percentage of red cells was calculated from total area covered by red cells divided by the total area covered by both green and red cells. Each data set contains at least six fields of view that are used for data quantification.

\subsection{Hydrogen peroxide $\left(\mathrm{H}_{2} \mathrm{O}_{2}\right)$ measurement}

Quantification of $\mathrm{H}_{2} \mathrm{O}_{2}$ concentration in the plasma liquid was performed following the protocol of Pick and Keisari. ${ }^{[28]}$ Briefly, $5 \mathrm{~g}$ of horseradish peroxidase Type II (Sigma Aldrich, Sydney, Australia) powder was dissolved in $0.05 \mathrm{M}$ phosphate buffer. Phenol red dye is used to detect colour change due to the presence of $\mathrm{H}_{2} \mathrm{O}_{2}$, using a concentration of $0.28 \mathrm{mM}$. Standard curves were then prepared by measuring spectra of milli-Q water containing various concentrations of $\mathrm{H}_{2} \mathrm{O}_{2}$ from $0-60 \mu \mathrm{M}$. The solution was taken out of the dish, transferred into 
138 a small glass vial, and incubated for 1 hour before spectra measurement. Just before spectra 139 measurement, $10 \mu \mathrm{L}$ of the horseradish peroxidase solution and $10 \mu \mathrm{L}$ of the phenol red 140 solution were added into the standard samples and plasma-treated liquid. These vials were 141 then incubated again at $25^{\circ} \mathrm{C}$ for 5 mins. After incubation, $\mathrm{NaOH}$ was added to the solution 142 to change its color from orange to purple and keep the colour stable. ${ }^{[28]}$ Spectra of samples at $143610 \mathrm{~nm}$ were then recorded using a UV-VIS spectrophotometer (Shimadzu Corporation, 144 Kyoto, Japan).

145

146

\section{Results \& Discussion}

\subsection{The effect of plasma treatment on biofilm structure}

Plasma treatment has been reported previously to destabilize biofilm structures. ${ }^{[21]}$ Here we use an Escherichia coli biofilm that is in a younger state than the previously studied biofilms of Pseudomonas aeruginosa or Staphylococcus aureus. ${ }^{[21]}$ During this early stage of biofilm development, no microcolonies have been formed. Figure $2 \mathrm{a}$ shows the microscopic initial state of these young biofilms, with green live cells visible throughout the field of view at $t=0$ s. Figure 2a also shows micrographs of the biofilm after different plasma exposure times, enabling tracking of the kinetic progression of cell death by following the increase in red, or dead, cells and the survival of the green, or living, cells and the formation of cell clumps. These effects are contrary to those reported by Ferrell et al, ${ }^{[21]}$ with plasma treatment inducing aggregation and forming a new structure rather than structure breakdown. This plasma-induced structural re-arrangement has been observed previously in surface-deposited planktonic bacteria. ${ }^{[29]}$

Figure 2a shows that cell aggregation occurred for all treatment times tested. However, quantitative analysis via cell imaging revealed that there was only a slight increase in the 
163 percentage of larger aggregates $\left(>10 \mu \mathrm{m}^{2}\right)$ as a function of treatment time (Figure 2b). An

164 aggregate area cutoff value of $10 \mu \mathrm{m}^{2}$ was chosen to differentiate aggregates from cells in

165 sufficient proximity to be classified as an aggregate. An increase was only observed between

166 the untreated and the shortest treatment time of $10 \mathrm{~s}$ (around $20 \%$ increase), indicating that

167 cell aggregation occurs rapidly and is not significantly governed by treatment time.

168 Figure $2 \mathrm{~b}$ shows that although plasma treatment causes cell aggregation, it also inactivates

169 bacterial cells in the biofilm. This behaviour has been observed in many studies that study the

170 effect of treatment on bacterial viability. ${ }^{[15-17]}$ However, for the current system, it is found that

171 after $40 \mathrm{~s}$ the number of dead cells reaches a plateau of $40 \%$, Figure $2 \mathrm{~b}$. This indicates that

172 there is a limit to the number of bacteria that can be killed with plasma treatment, perhaps

173 because aggregation offers some form of protection.

174 Of particular interest is that the aggregation of the cells and the mortality effects of the plasma

175 appear to both plateau, although on different time scales, after $40 \mathrm{~s}$ for cell viability and after

$17610 \mathrm{~s}$ for cell aggregation (Figure $2 \mathrm{~b}$ ).

177 The biofilms used in this study are considered mature once they are $48 \mathrm{~h}$ old, but we also

178 examined the effects of biofilm age on aggregation and mortality response to plasma

179 treatment. This is because the amount of EPS increases with biofilm age, and it may play a

180 role in protecting cells from plasma and aggregation induced by plasma.

181 When subjected to the same plasma treatment for $30 \mathrm{~s}$, both biofilms aged $24 \mathrm{~h}$ and $48 \mathrm{~h}$ form

182 aggregates (Figure 3a). The percentage of big aggregates formed in these two samples is quite

183 similar, although the actual percentage of bigger clumps is slightly higher for the treated

184 younger biofilm. The older biofilm is expected to have more EPS, which might explain why

185 there is a slight discrepancy between the two values. Aggregation requires both attractive

186 interactions between cells and sufficient mobility to bring cells together for collision. The 
187 cells in the older biofilm might move less than the cells in younger ones, resulting in the 188 current observation.

189 Figure 3 also shows that older biofilms have increased resistance to plasma treatment. In 190 Figure 3c, the percentage of dead cells after treatment increased compared to the control. For 191 biofilms aged $24 \mathrm{~h}$, the percentage of dead cells increases from around $2 \%$ to $40 \%$ upon 192 treatment. The efficacy of plasma decreases with increasing age of biofilm, as the percentage 193 of dead cells only increases from $2 \%$ to $25 \%$ upon treatment, about half of the impact seen for 194 biofilms aged $24 \mathrm{~h}$.

195

\subsection{Regrowth of surviving bacteria}

197

When plasma treatment does not inactivate all bacterial cells in a biofilm, the surviving cells may be able to grow and reproduce when given sufficient nutrients. Under these circumstances, we are interested in how these bacterial cells regrow in their restructured environment. To answer this question, both younger and more mature biofilms were exposed to plasma treatment and then regrown, until the biofilm reached an age of $72 \mathrm{~h}$, before being imaged.

Biofilms that have been treated at least once after regrowth have distinct structures when compared to previously untreated biofilms with the same treatment. Figure 4a indicates that biofilms treated at least once during their growth have clearly aggregated structures compared to untreated biofilms that retain a fully dispersed structure. Indeed, after plasma treatment of

208 biofilms either $24 \mathrm{~h}$ or $48 \mathrm{~h}$ old, bacteria keep growing in the aggregates instead of growing 209 separately as in the untreated samples. This indicates that the surviving bacteria are able to 210 reproduce and grow in this newly formed structure.

211 Yet, these aggregated structures that occur after treatment at $24 \mathrm{~h}$ and $48 \mathrm{~h}$, or treated twice at $21224 \mathrm{~h} 48 \mathrm{~h}$ old, are hardly distinguishable from each other. Quantitative analysis on the Wirey- $10 \mathrm{CH}$ 
213 aggregates (Figure 4b) reveals that biofilms treated at $24 \mathrm{~h}$ have a higher percentage of 214 aggregates larger than $10 \mu \mathrm{m}^{2}$ than a biofilm treated at $48 \mathrm{~h}$ or treated at $24 \mathrm{~h} \& 48 \mathrm{~h}$. This 215 may be due to fact that biofilms treated at $24 \mathrm{~h}$ have more time to expand the size of their 216 colonies as longer growth time increases cell cluster size. ${ }^{[30]}$

217 In addition, as seen from Figure 4a, a plasma-treated biofilm consists of only living cells. 218 Analysis shows that despite $30 \mathrm{~s}$ of plasma treatment causing cell death of a significant 219 proportion of cells (Figure 4c), only a very small number $(<10 \%)$ of dead cells could be 220 detected after biofilm re-growth. However, it is likely that some dead cells are hidden within 221 the new structure. However, the percentage of these red cells is still quite low, less than $10 \%$, 222 which is not significant.

\subsection{The effect of plasma-induced biofilm structure on subsequent treatment}

In section 3.2 , it was found that after plasma treatment, bacteria in a biofilm can utilize the new structure to reproduce and grow. In previous work by Ferrell et al, ${ }^{[21]}$ a mature biofilm with large aggregates was shown to change structure by increasing the porosity of the biofilm structure. In this kind of mature biofilm, the high amount of EPS should prevent the aggregation of bacteria as this EPS provides elastic resistance to deformation by flow. The plasma-treated biofilm has a structure more similar to the mature biofilm used by Ferrell et $a l{ }^{[21]}$ It is interesting to know if this plasma-mediated structure has a similar behaviour to a 234 mature biofilm.

235 To answer this, biofilms were exposed to plasma after $24 \mathrm{~h}$ of growth. This sample is

236 incubated again for another $24 \mathrm{~h}$ before exposing this to the second plasma treatment. Figure 237 5a shows that clumping is still apparent in this system. However, quantitative analysis shows 
238 that the relative amount of aggregates decreases after the second plasma treatment instead of 239 increasing. This observation agrees with Ferrell et al. 's ${ }^{[21]}$ work. This also indicates that after 240 a certain point, aggregation is not possible anymore as biofilms might produce enough EPS to 241 resist deformation by plasma. Another explanation is that subsequent plasma treatments can 242 destroy structures formed by previous treatments.

243 Interestingly, Figure 5a also indicates that biofilms that have been previously treated mainly 244 consist of live cells. This result is unexpected as when the sample is treated twice, it is likely 245 that the percentage of red cells should be higher compared to $24 \mathrm{~h}$ or $48 \mathrm{~h}$ old biofilms. As 246 can be seen from Figure 5c, the percentage of dead cells in the sample treated both at $24 \mathrm{~h}$ and $24748 \mathrm{~h}$ is about $5 \%$ which is much lower than the percentage of cells inactivated by single 248 treatment when they were $24 \mathrm{~h}$ (by 6 times) or $48 \mathrm{~h}$ old (by 4 times). This suggests that the 249 bacteria developed resistance after the first treatment that reduced efficacy of the second 250 treatment, consistent with other reports of resistant colonies induced by plasma treatment. ${ }^{[16,}$ $25131]$

\subsection{The effect of plasma chemicals on biofilm structure}

254 In the literature, the death of bacterial cells induced by plasma is usually associated with the 255 presence of reactive species produced by plasma treatment. It is plausible that such chemicals 256 could also cause clumping, as bacteria are known to respond to chemicals present via 257 chemotaxis. Chemotaxis is the phenomenon by which motile cells move towards or away 258 from a chemical by altering their swimming pattern. Bacteria such as E. coli have several 259 flagella per cell which facilitate some directional control over their motion to either find 260 favourable locations with high concentrations of attractants or to avoid repellents, ${ }^{[32]}$ such as 261 chemicals produced by plasma. Although chemotaxis traditionally is known only for motile 262 cells, recent finding shows that chemotaxis might also occur in surface-attached cells. ${ }^{[33]}$ 
264 One of the chemicals often found in atmospheric plasma-treated liquid is $\mathrm{H}_{2} \mathrm{O}_{2}{ }^{[19,34]}$ For this

265 work only $\mathrm{H}_{2} \mathrm{O}_{2}$ is measured, for a more comprehensive species diagnostic of PAW using this 266 power source, the reader is referred to our recent publications. ${ }^{[25,35]}$ Figure $6 \mathrm{~b}$ indicates that 267 the concentration of $\mathrm{H}_{2} \mathrm{O}_{2}$ in the liquid increases with increasing treatment time. This 268 behaviour has been seen in plasma-treated water previously, where initially the concentration 269 of peroxide increases linearly before reaching a plateau. ${ }^{[25]}$

270 If the aggregation observed previously is related to the presence of chemicals produced by 271 plasma reactive species, we should be able to induce such aggregation by adding commercial $272 \mathrm{H}_{2} \mathrm{O}_{2}$, or plasma-treated water, to the biofilms and comparing the result to plasma-treated 273 biofilms. The concentration of $\mathrm{H}_{2} \mathrm{O}_{2}$ added to the liquid is the same as the concentration of $274 \mathrm{H}_{2} \mathrm{O}_{2}$ in water treated in plasma for $60 \mathrm{~s}$, which is $30 \mu \mathrm{M}$.

276 Figure 7a shows that biofilms that were exposed to plasma-treated liquid or $30 \mu \mathrm{M}$ peroxide 277 solutions are similar to the control. Data analysis (Figure $7 \mathrm{~b}$ ) reveals that there are actually 278 changes in clumping after addition of peroxide or incubation with plasma water compared to 279 control. Figure $7 \mathrm{~b}$ also shows that compared to peroxide only, plasma water increases the 280 extent of clumping by 2 times (from 3\% to 6\%), which might suggest that presence of other 281 chemicals that also give rise to cell clumping. However, the change in clumping caused by 282 chemicals $(\sim 6 \%)$ is not as much as the clumping caused by direct treatment $(\sim 20 \%)$. This 283 suggests that aggregate formation might be slightly affected by chemicals present in plasma284 treated water, but it is not the main mechanism. Movement of bacteria is also required for 285 aggregation and is likely controlled by plasma discharge-induced flow. ${ }^{[28]}$

286 Additionally, the use of hydrogen peroxide and plasma liquid here does not cause significant 287 cell death. As shown in Figure 7b, the percentage of cells killed by treatment is very small, 288 less than $2 \%$. These values are similar to the levels in untreated biofilms. This means there is 
289

290

291

292

293

very little effect of plasma-treated water, which is not in agreement with literature as plasmatreated liquid has been shown to inactivate bacteria in biofilms. ${ }^{[36,37]}$ But, literature ${ }^{[38,39]}$ has indicated that in order for plasma-treated liquid to be effective in inactivating bacteria, acidified conditions are required. Naïtali et $a l^{[38]}$ showed that in plasma-treated water, a bacterial population was reduced from $8 \log$ CFU to $2 \log$ CFU. However, the effect was diminished for buffered plasma liquid where only a minimal reduction was observed. As all experiments here use a buffer solution, $\mathrm{PBS}$, the $\mathrm{pH}$ of the solution is not expected to change and become acidified.

\subsection{Dilution effect on biofilm structure}

As mentioned before, the formation of ring structure has been observed in surface deposited bacteria, which is said due to drying by plasma jet. ${ }^{[29]}$ This means that there is high possibility that the structure here is also caused by drying. To understand better the drying by our plasma system, we measured how much water removed when exposed to plasma.

Table 2 shows that for 30s treatment time, plasma treatment removes between $0.04-0.06 \mathrm{~g}$ water from the system by evaporation regardless of the starting amount of water. From this result, it appears that there is a maximum amount of water that can be removed by plasma for the same treatment time. On the other hand, Table 2 also indicates that the percentage of water removed changes depending on the amount of initial liquid covering biofilm. In this case, the maximum of water removed is $32.9 \%$ for a biofilm covered with $200 \mu \mathrm{L}$ of water (Table 2). Additionally, this suggests that after plasma treatment for 30 s, biofilms will not completely dry out. Thus, from this observation it is therefore likely that larger volumes of water could reduce the drying and convective effects of plasma treatment in a specified 
313 treatment time. Interestingly, we have observed that biofilms that were completely dried in an

314 oven overnight have a similar structure to these plasma-treated samples (data not shown).

315 The above experiments were repeated with biofilms present in varying amounts of water and

316 a constant plasma exposure time of 30s. Figure 8 summarizes the results obtained from this

317 experiment. It is clear that biofilms can aggregate in liquid volumes up to $600 \mu$ l. However,

318 when biofilms are in larger liquid volumes $(>600 \mu \mathrm{l})$ no aggregation was observed,

319 presumably due to a protective effect from the liquid against drying.

320 Figure $8 \mathrm{~b}$ also indicates that aggregation and cell death was steadily reduced with increasing 321 amounts of liquid. Increasing the amount of water by $200 \mu \mathrm{L}$ lowers the percentage of dead 322 cells and also reduces the extent of clumping by around $10 \%$. For biofilms that are covered by $323800 \mu \mathrm{L}$ and $1000 \mu \mathrm{L}$, the clumping effect and amount of cell death is very small. This 324 confirms the hypothesis that extra liquid protects biofilms during plasma treatment and 325 reduces the drying effect imposed by plasma discharge. Although plasma drying is not 326 mentioned much in the literature as a mechanism of plasma inactivation, it is an important 327 factor governing cell death. Due to this, the effect of plasma drying during treatment has to be 328 taken into account when treating bacteria or biofilms, as this effect is apparent even when 329 biofilms are treated for very short times.

\section{$332 \quad 3.6$ Explanation of structure formation}

333 Our results from the previous section indicate that the structure generated by plasma treatment

334 is mainly due to a drying effect. There is a difference in the convection produced by plasma 335 and standard oven, as Figure $10 \mathrm{a} \& \mathrm{~b}$ indicates treatment with a conventional oven at $50^{\circ} \mathrm{C}$ 336 (average temperature of cold plasma) for the same time scale (30 s or $60 \mathrm{~s}$ ) could not cause 337 the same effect of aggregation. In addition, as can be seen from Figure 10c, even prolonged Wirey $15 \mathrm{VCH}$ 
338 dehydration for 90 s using the oven could not cause the same clumping effect as plasma 339 treatment, although there is idication of some cell death.

340 The circular pattern observed in Figure 9a resembles Benard cells, hexagonally-ordered 341 structures that spontaneously form in fluids with a convection flow during heating or 342 evaporation. ${ }^{[40]}$ The length scale of this structure is on the order of $\mu \mathrm{m}$ and is similar to 343 structures formed by surface-deposited bacteria, ${ }^{[29]}$ as depicted in Figure 9c.

344 Deegan et al ${ }^{[41]}$ showed that various patterns can be created by changing the conditions of 345 evaporation. Apart from the formation of Benard cells where the deposit forms a ring, Deegan 346 et $a^{[41]}$ also observed the formation of compact structures as we observed in our biofilm 347 (Figure 9b). As biofilms are known to have a heterogeneous spatial structure, the plasma jets 348 are also generally heterogeneous in their effects on targets, resulting in the two distinct 349 structures observed. Fischer ${ }^{[42]}$ reported the formation of such ring structures only occurs 350 when there is outward flow to replenish liquid evaporating from the edges.

351 The fact that there is a limit of maximum liquid coverage of biofilms for significant 352 convective effects may be related to the conditions required for Benard cell formation in thin 353 films, namely that the thickness be less than $1 \mathrm{~mm} .{ }^{[43]} \mathrm{In}$ our experiments, water mainly 354 covered the inner area of the FluoroDish ${ }^{\mathrm{TM}}$, which has an overall diameter of $23.5 \mathrm{~mm}$. 355 Assuming that liquid covers the inner area uniformly and the area is in cylindrical shape, the 356 volume of liquid added to each system allows us to calculate the height of liquid covering the 357 biofilm. It was found that only biofilm containing $200 \mu \mathrm{L}$ and $400 \mu \mathrm{L}$ liquid is covered by 358 water layer which is less than $1 \mathrm{~mm}$ thick. This agrees with the finding that aggregation of 359 cells is more apparent in those samples.

360 Drying of $200 \mu \mathrm{L}$ water for $30 \mathrm{~s}$ by oven only removed $1.6 \pm 0.25 \%$ water, which is around 20 361 times lower than drying the same amount of water by plasma (Table 2). Probstein ${ }^{[43]}$ also 
362 indicates that for thin films around 0.5-1 mm deep, the cell spacing should be around three

363 times the liquid depth. The difference between the two might relate to the different rate of

364 drying of plasma, oven or natural convection. In addition, the fact that biofilms have

365 polymeric gels that encapsulate them, might reduce the rate of bacterial cell migration during

366 drying, hence smaller size structures were observed.

\section{Conclusions}

369 Plasma can be an effective treatment for biofilm eradication. However, this study found that

370 plasma can also induce new structures within the biofilm, which can persist after treatment

371 during regrowth. This phenomenon was evident for both young and more mature biofilms.

372 Once such structures form, subsequent treatments are less effective in terms of efficacy, likely

373 due to the surviving bacteria becoming increasingly resistant to plasma. The structures

374 induced for the biofilms tested are similar to those observed previously for plasma-treated

375 surface-deposited bacteria. ${ }^{[29]}$ The observed structures are reminiscent of Benard cells, whose

376 main mechanism of formation is convection. Secondary plasma species formed in the liquid

377 phase were not found to induce the formation of such structures. 
Table 1. Design of regrowth experiment where $\mathrm{U}$ indicates untreated and T treated samples

\begin{tabular}{lllll}
\hline Biofilm age (h) & Control & Treatment & & \\
\hline $\mathbf{2 4}$ & $\mathrm{U}$ & $\mathrm{T} 24$ & & \\
$\mathbf{4 8}$ & $\mathrm{U}$ & $\mathrm{T} 48$ & $\mathrm{~T} 24+48$ & $\mathrm{~T} 48$ \\
$\mathbf{7 2}$ & $\mathrm{U}$ & $\mathrm{T} 24+48$ & $\mathrm{~T} 24$ & \\
\hline
\end{tabular}

Table 2. The amount of water removed by plasma treatment

\begin{tabular}{ccc}
\hline Amount of water in dish $(\boldsymbol{\mu L})$ & Amount of water removed (g) & Percentage of water removed \\
$(\mathbf{\%})$ \\
\hline 200 & $0.064 \pm 0.024$ & $32.9 \pm 2.7$ \\
400 & $0.053 \pm 0.007$ & $13.3 \pm 1.7$ \\
600 & $0.044 \pm 0.011$ & $7.4 \pm 1.9$ \\
800 & & $7.5 \pm 2.3$ \\
1000 & $0.060 \pm 0.019$ & $5.1 \pm 1.3$ \\
\hline
\end{tabular}




\section{References}

1. H.-C. Flemming and J. Wingender, Nat Rev Micro, 2010. 8(9): p. 623-633.

2. $\quad$ T.-F.C. Mah and G.A. O'Toole, Curr Trends Microbiol., 2001. 9(1): p. 34-39.

3. R.M. Donlan, Emerg. Infect. Dis., 2001. 7(2): p. 277.

4. $\quad$ R.M. Donlan, Emerg. Infect. Dis., 2002. 8(9): p. 881-890.

5. L. Hall-Stoodley, J.W. Costerton, and P. Stoodley, Nat Rev Micro, 2004. 2(2): p. 95-108.

6. S. Srey, I.K. Jahid, and S.-D. Ha, Food Control, 2013. 31(2): p. 572-585.

7. A. Birjiniuk, N. Billings, E. Nance, J. Hanes, K. Ribbeck, and P.S. Doyle, New J. Phys., 2014. 16(8): p. 085014.

8. E.J. Stewart, M. Ganesan, J.G. Younger, and M.J. Solomon, Sci. Rep., 2015. 5: p. 13081.

9. M. Chen, Q. Yu, and H. Sun, Int. J. Mol. Sci., 2013. 14(9).

10. N.N. Misra, B.K. Tiwari, K.S.M.S. Raghavarao, and P.J. Cullen, Food Eng Rev, 2011. 3(3): p. 159-170.

11. C. Tendero, C. Tixier, P. Tristant, J. Desmaison, and P. Leprince, Spectrochim. Acta B, 2006. 61(1): p. 2-30.

12. S.G. Joshi, M. Paff, G. Friedman, G. Fridman, A. Fridman, and A.D. Brooks, Am J Infect Control, 2010. 38(4): p. 293-301.

13. Z. Xiong, T. Du, X. Lu, Y. Cao, and Y. Pan, Appl. Phys. Lett., 2011. 98(22): p. 221503.

14. M.Y. Alkawareek, Q.T. Algwari, G. Laverty, S.P. Gorman, W.G. Graham, D. O'Connell, and B.F. Gilmore, PLOS ONE, 2012. 7(8): p. e44289.

15. D. Ziuzina, S. Patil, P.J. Cullen, D. Boehm, and P. Bourke, Plasma Medicine, 2014. 4(1-4): p. 137-152.

16. A. Mai-Prochnow, M. Bradbury, K. Ostrikov, and A.B. Murphy, PLOS ONE, 2015. 10(6): p. e0130373.

17. D. Ziuzina, D. Boehm, S. Patil, P.J. Cullen, and P. Bourke, PLoS ONE, 2015. 10(9): p. e0138209.

18. D.X. Liu, Z.C. Liu, C. Chen, A.J. Yang, D. Li, M.Z. Rong, H.L. Chen, and M.G. Kong, Sci. Rep., 2016. 6: p. 23737.

19. L.F. Gaunt, C.B. Beggs, and G.E. Georghiou, IEEE Trans. Plasma Sci., 2006. 34(4): p. 12571269.

20. J.T. Matthew, J.P. Matthew, K. Sharmin, H. Pritha, S. Yukinori, S.C. Douglas, and B.G. David, J. Phys. D, 2011. 44(47): p. 472001.

21. J.R. Ferrell, F. Shen, S.F. Grey, and C.J. Woolverton, Biofouling, 2013. 29(5): p. 585-599.

22. M.S.I. Khan, E.-J. Lee, and Y.-J. Kim, Sci. Rep., 2016. 6: p. 37072.

23. A.J. Zelaya, G. Stough, N. Rad, K. Vandervoort, and G. Brelles-Mariño, IEEE Trans. Plasma Sci., 2010. 38(12): p. 3398-3403.

24. K.G. Vandervoort and G. Brelles-Mariño, PLOS ONE, 2014. 9(10): p. e108512.

25. P. Lu, D. Boehm, P. Bourke, and P.J. Cullen, Plasma Process Polym., 2017: p. e1600207-n/a.

26. C.A. Schneider, W.S. Rasband, and K.W. Eliceiri, Nat Meth, 2012. 9(7): p. 671-675.

27. G. Reshes, S. Vanounou, I. Fishov, and M. Feingold, Biophys. J., 2008. 94(1): p. 251-264.

28. E. Pick and Y. Keisari, J Immunol Methods, 1980. 38(1): p. 161-170.

29. D.L. Bayliss, J.L. Walsh, F. Iza, G. Shama, J. Holah, and M.G. Kong, Plasma Process Polym., 2012. 9(6): p. 597-611.

30. H. Beyenal, Z. Lewandowski, and G. Harkin, Biofouling, 2004. 20(1): p. 1-23.

31. R.E.J. Sladek, S.K. Filoche, C.H. Sissons, and E. Stoffels, Lett Appl Microbiol, 2007. 45(3): p. 318-323.

32. J. Adler, Science, 1966. 153(3737): p. 708-716.

33. N.M. Oliveira, K.R. Foster, and W.M. Durham, Proc. Natl. Acad. Sci. U.S.A., 2016. 113(23): p. 6532-6537.

34. K. Oehmigen, J. Winter, M. Hähnel, C. Wilke, R. Brandenburg, K.-D. Weltmann, and T. von Woedtke, Plasma Process Polym., 2011. 8(10): p. 904-913.

35. P. Lu, D. Boehm, P. Cullen, and P. Bourke, Appl. Phys. Lett., 2017. 110(26): p. 264102. 
36. U. Ercan, Joshi, S. , Yost, A. , Gogotsi, N. , O'Toole, S. , Paff, M. , Melchior, E. and Joshi, S., Adv Microbiol., 2014. 4: p. 1188-1196.

37. G. Kamgang-Youbi, J.M. Herry, T. Meylheuc, J.L. Brisset, M.N. Bellon-Fontaine, A. Doubla, and M. Naïtali, Lett Appl Microbiol, 2009. 48(1): p. 13-18.

38. M. Naïtali, G. Kamgang-Youbi, J.-M. Herry, M.-N. Bellon-Fontaine, and J.-L. Brisset, Appl. Environ. Microbiol., 2010. 76(22): p. 7662-7664.

39. K. Oehmigen, M. Hähnel, R. Brandenburg, C. Wilke, K.D. Weltmann, and T. von Woedtke, Plasma Process Polym., 2010. 7(3-4): p. 250-257.

40. L. Rayleigh, Philos. Mag., 1916. 32(192): p. 529-546.

41. R.D. Deegan, O. Bakajin, T.F. Dupont, G. Huber, S.R. Nagel, and T.A. Witten, Phys Rev E, 2000. 62(1): p. 756-765.

42. B.J. Fischer, Langmuir, 2002. 18(1): p. 60-67.

43. R.F. Probstein, Surface Tension, in Physicochemical Hydrodynamics. 1993, Wiley. p. $267-318$. 


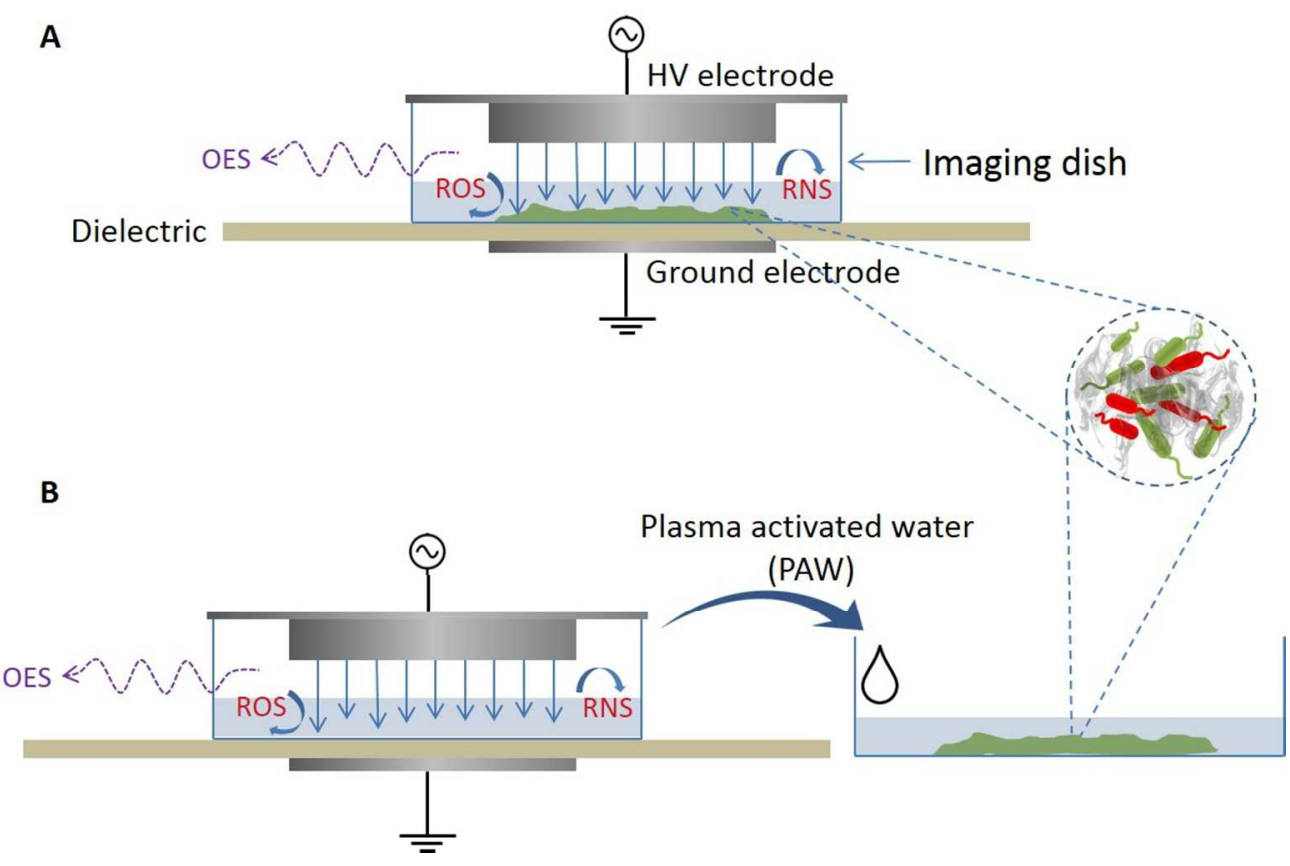

Figure 1. a) DBD design incorporating the glass bottom imaging dish containing the growing biofilm within the discharge gap, b) Schematic of air discharge in contact with liquid and addition of PAL to growing biofilm.

$206 \times 134 \mathrm{~mm}(150 \times 150 \mathrm{DPI})$ 
a)
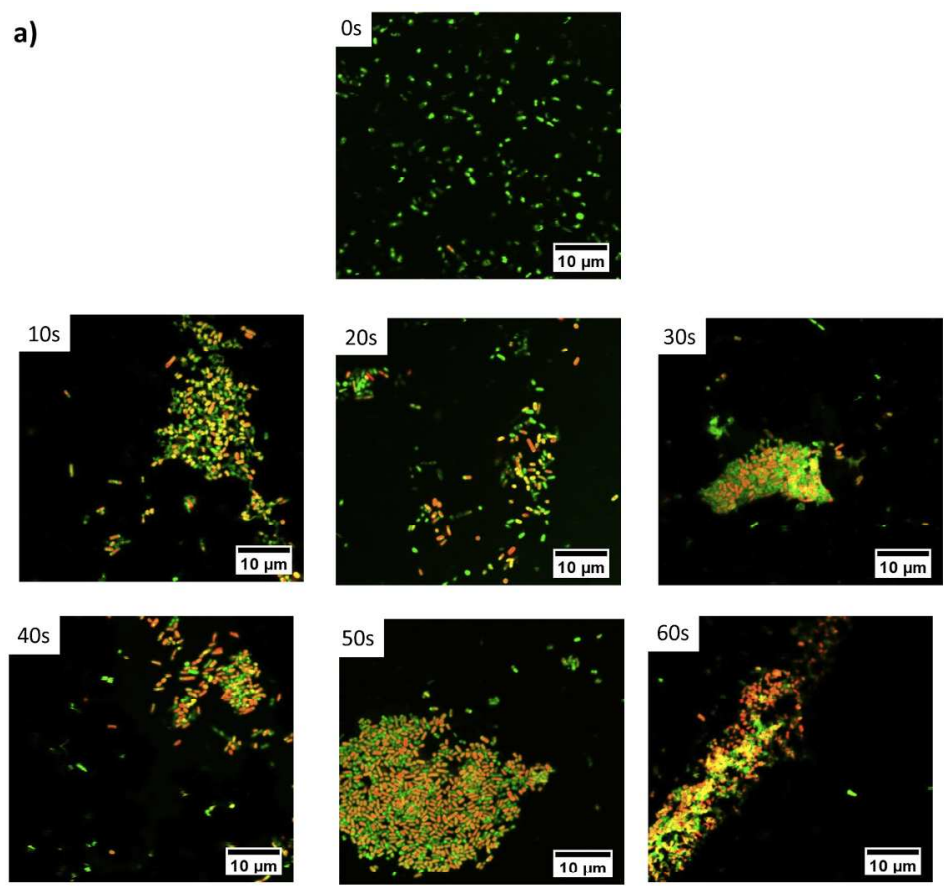

b)

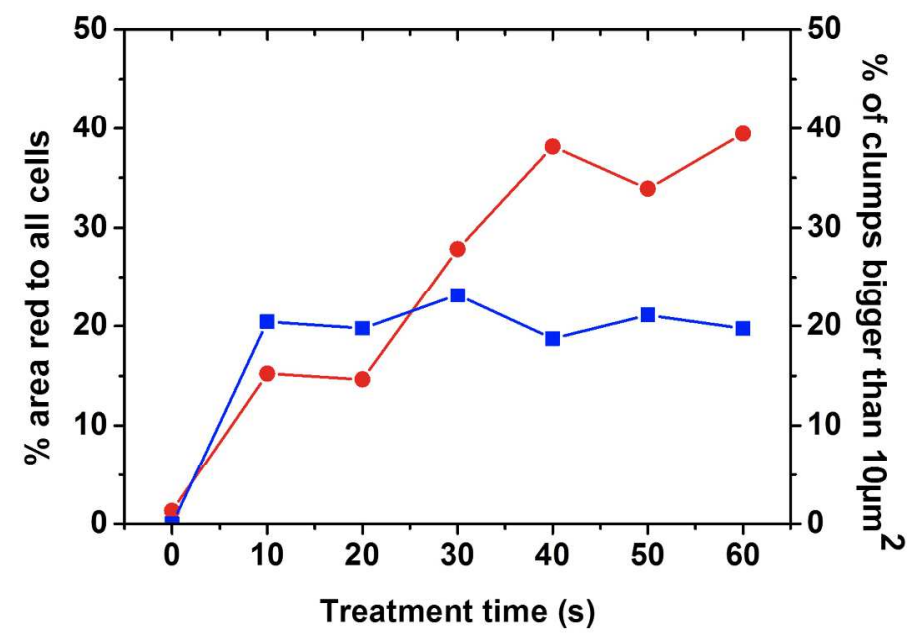

Figure 2. Effect of treatment time on biofilm structure a) Confocal images of biofilm structure before and after plasma treatment, b) quantification of dead cells (symbol •) and cell clumps larger than $20 \mu \mathrm{m} 2$ (symbol )

$293 \times 467 \mathrm{~mm}(300 \times 300 \mathrm{DPI})$ 

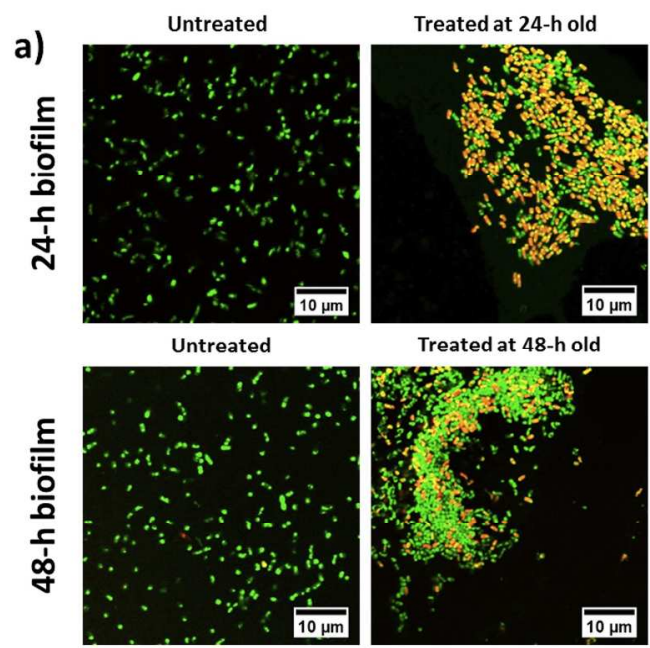

Treated at 48-h old
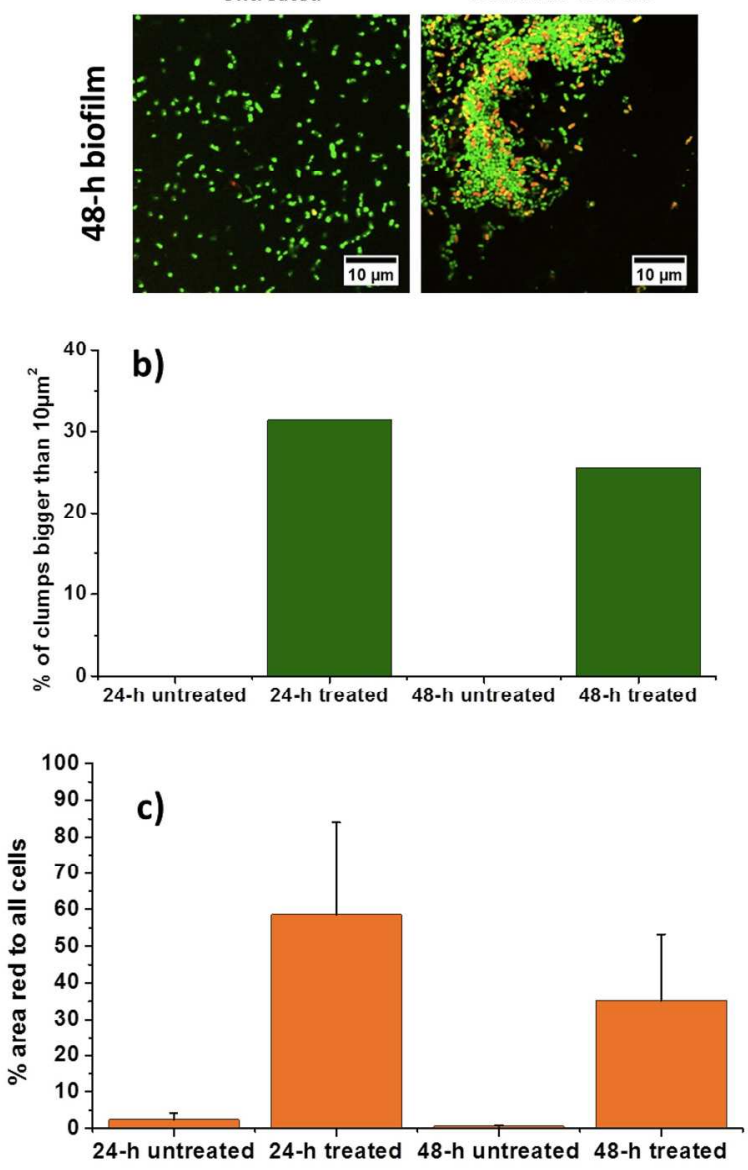

Figure 3. Effect of biofilm maturity on plasma clumping a) confocal images of 24-h and 48-h of untreated and plasma treated biofilm, b) percentage of clumps bigger than $20 \mu \mathrm{m} 2$, c) quantification of red cells.

$172 \times 281 \mathrm{~mm}(300 \times 300$ DPI $)$ 

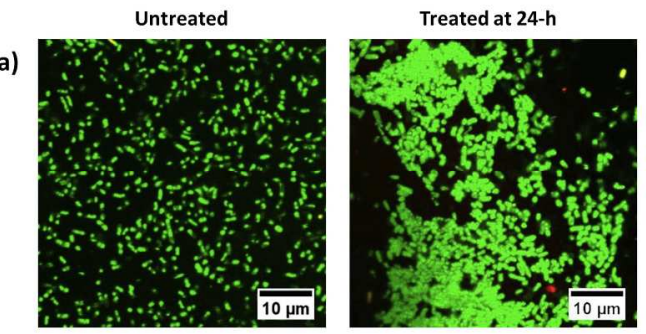

Treated at 48-h

Treated at 24-h \& 48-h
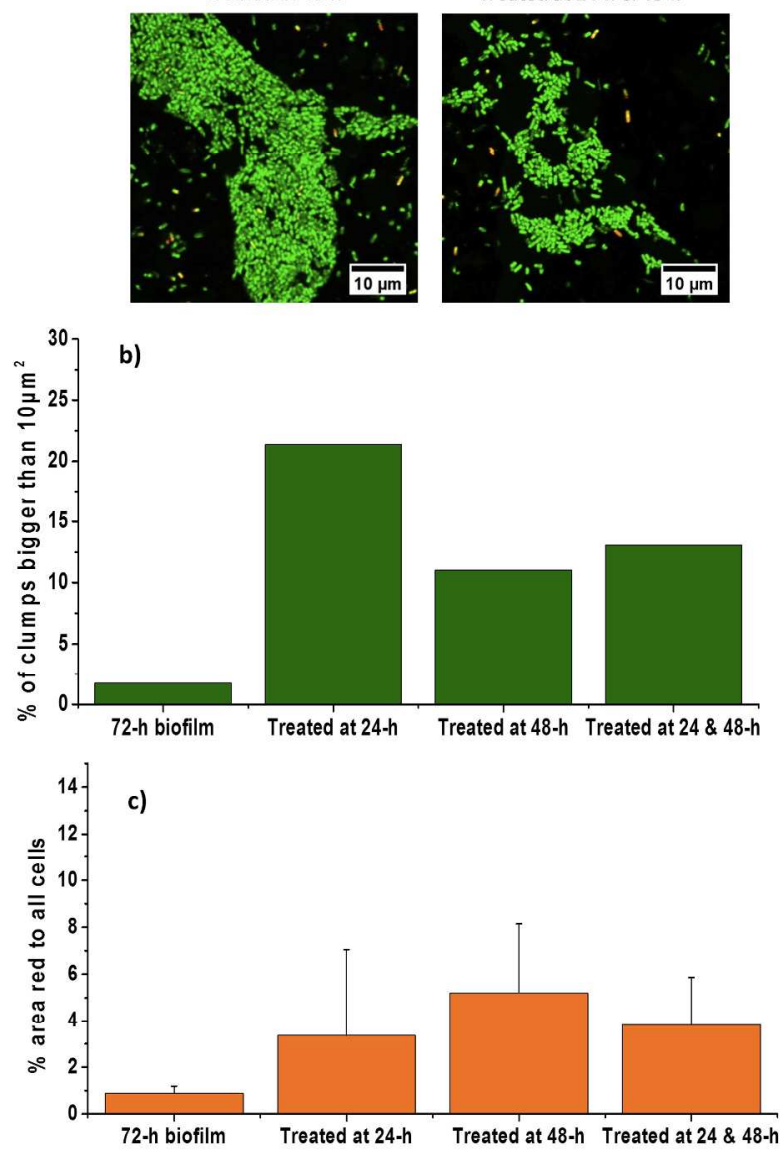

Figure 4. a) Confocal images of untreated 72-h biofilm and biofilm grown for 72-h but exposed to 30s plasma treatment at different biofilm ages, where it is shown that biofilms retain their aggregated structure after those plasma treatments, b) percentage of clumps bigger than $10 \mu \mathrm{m} 2$, c) quantification of red cells

$330 \times 505 \mathrm{~mm}(300 \times 300$ DPI) 
a)

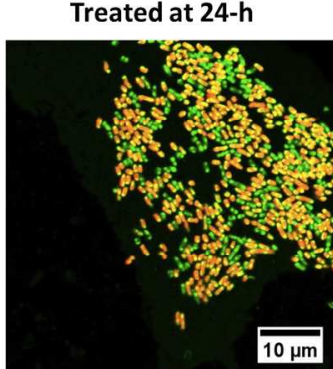

Treated at 48-h

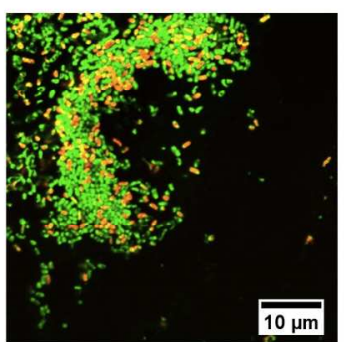

b)
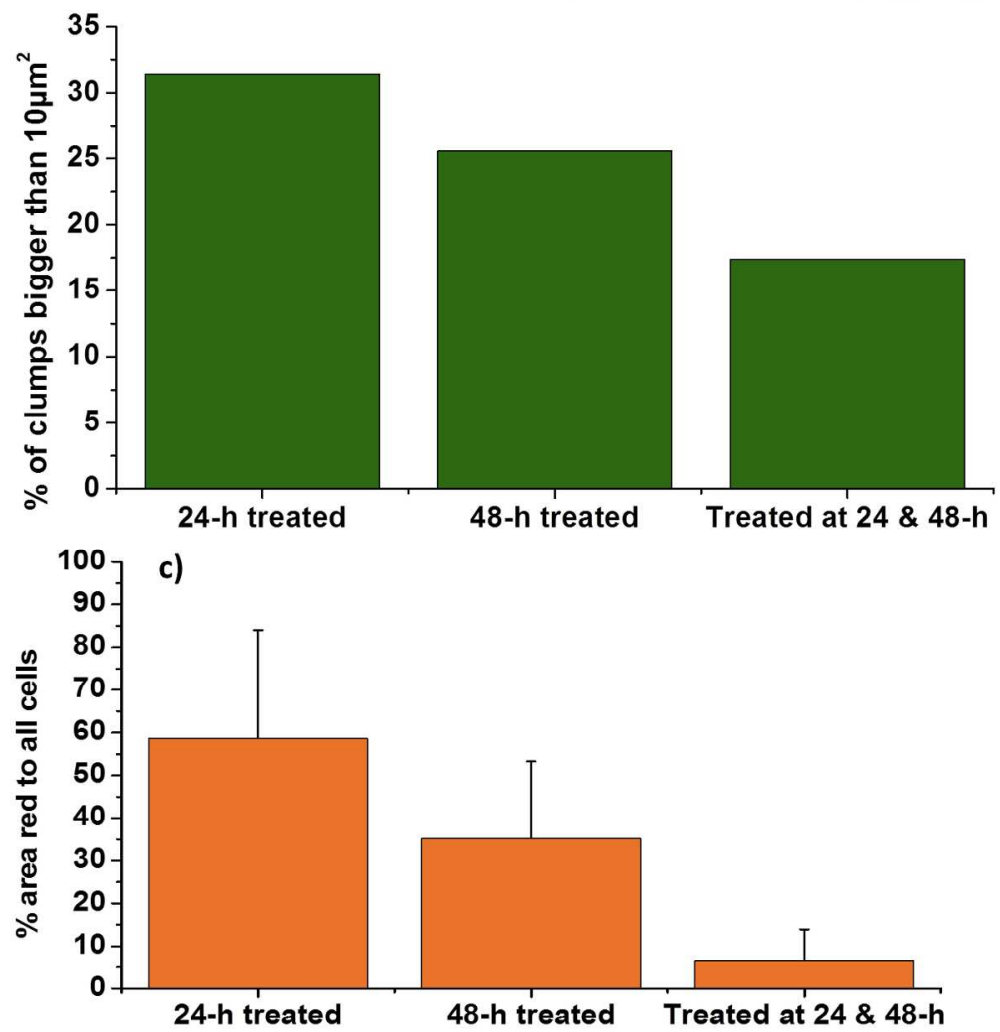

Figure 5. a) Confocal imaging of plasma-treated samples that were imaged right after treatment where less cells are killed after treated twice, b) the percentage of aggregates bigger than $10 \mu \mathrm{m} 2, \mathrm{c}$ ) quantification of dead cells

$314 \times 358 \mathrm{~mm}(300 \times 300$ DPI $)$ 

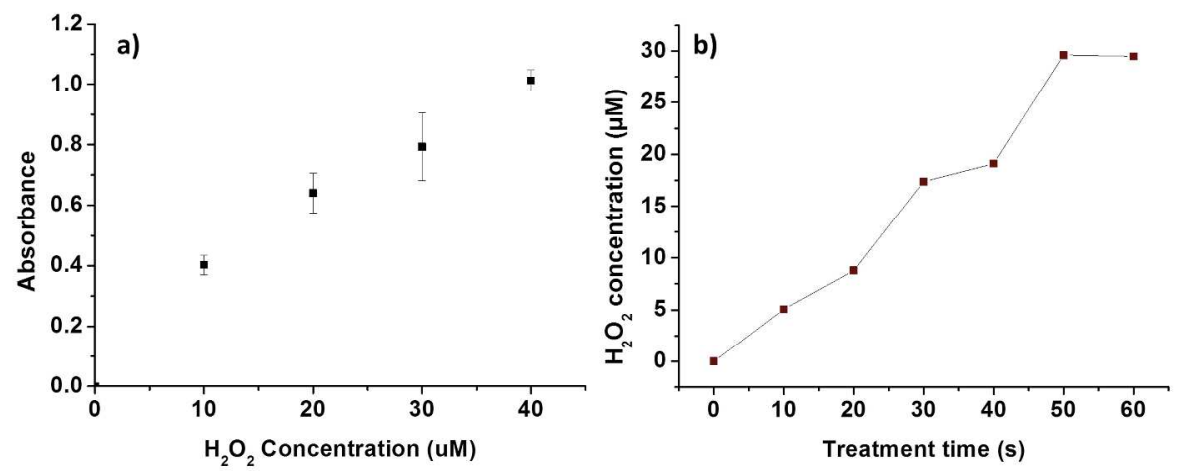

Figure 6. a) Calibration curve for $\mathrm{H} 2 \mathrm{O} 2$ by spectrometer at $610 \mathrm{~nm}$, b) The $\mathrm{H} 2 \mathrm{O} 2$ concentration in plasmatreated liquid.

$469 \times 182 \mathrm{~mm}(300 \times 300 \mathrm{DPI})$ 
a)

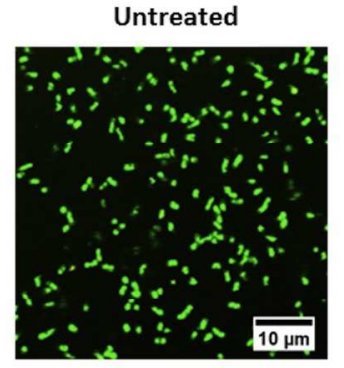

$30 \mu \mathrm{M} \mathrm{H} \mathrm{H}_{2} \mathrm{O}_{2}$

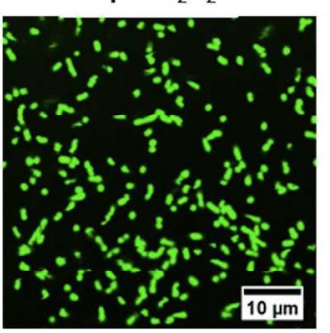

Plasma water

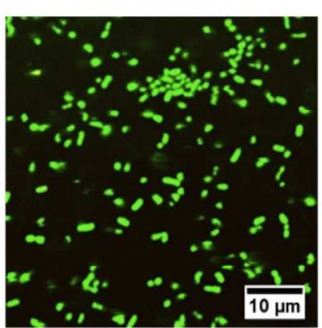

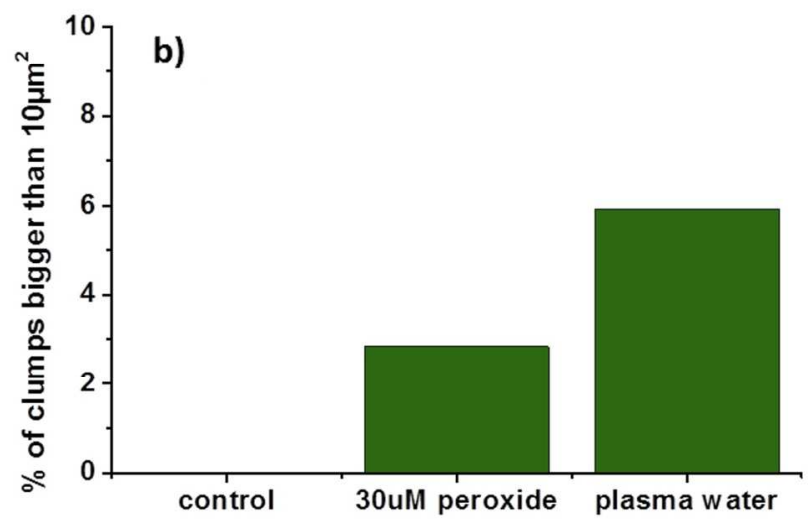

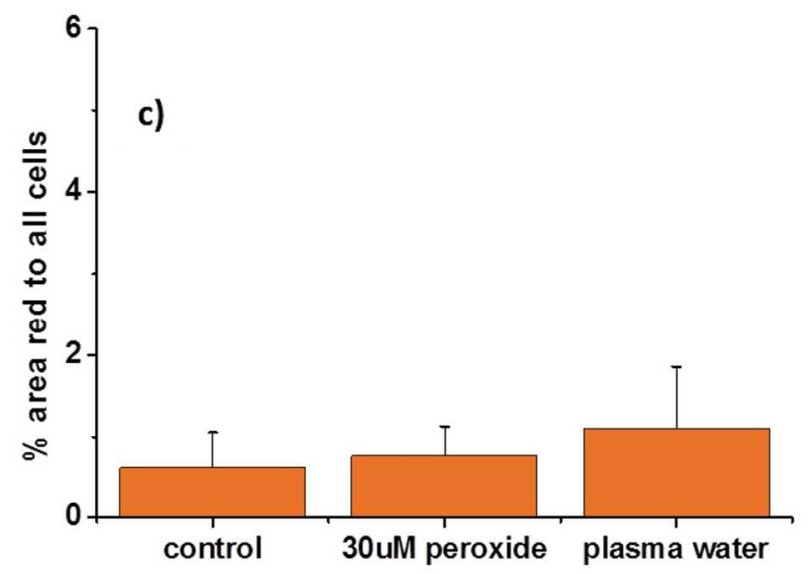

Figure 7. a) Confocal images of untreated biofilm, incubated with $30 \mu \mathrm{M} \mathrm{H} 2 \mathrm{O} 2$ and incubated with plasma liquid treated for $60 \mathrm{~s}, \mathrm{~b})$ percentage of aggregates bigger than $10 \mu \mathrm{m} 2, \mathrm{c}$ ) red cells quantification of samples

$144 \times 199 \mathrm{~mm}(300 \times 300 \mathrm{DPI})$ 
a)
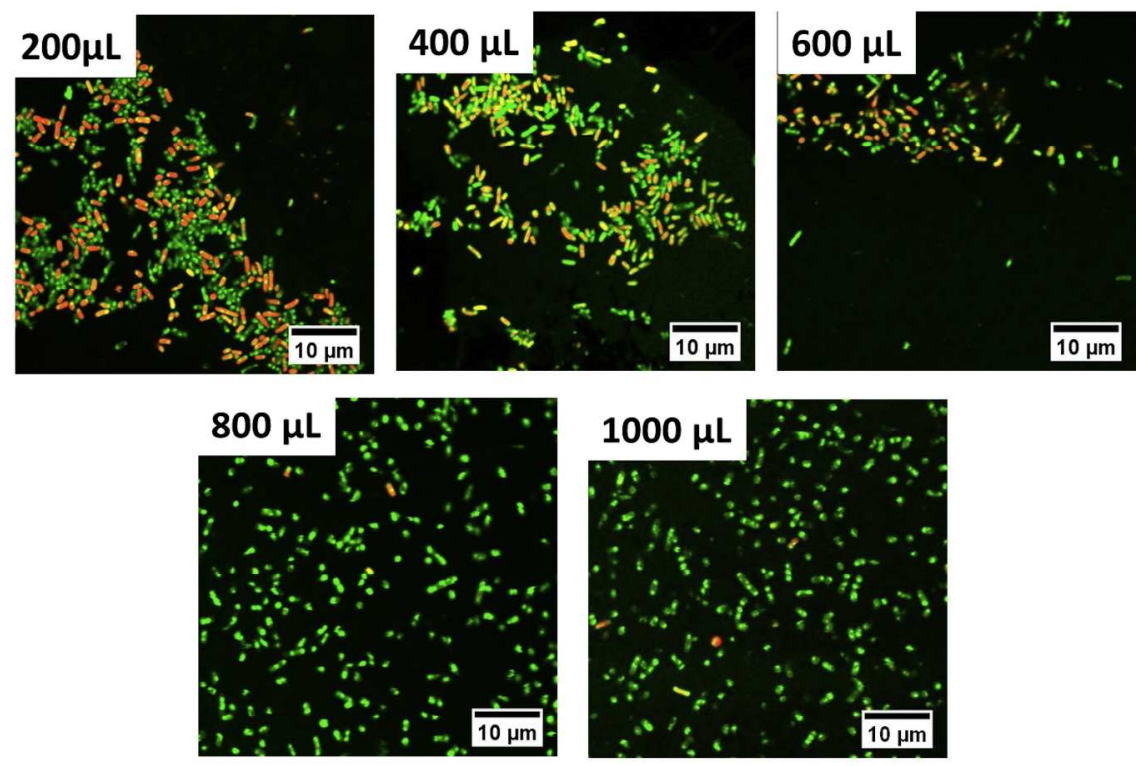

b)

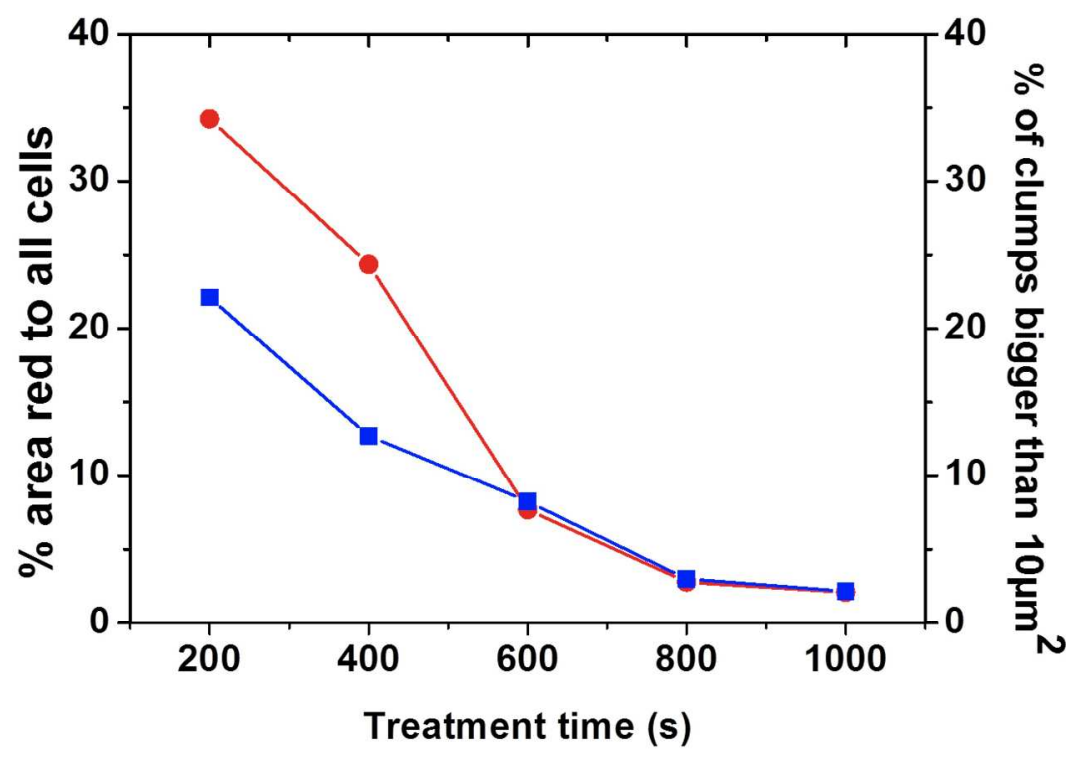

Figure 8 . The effect of liquid volume covering biofilm during plasma treatment on aggregation and cell death a) confocal images of different structures observed, b) quantification of dead cells (symbol $\bullet$ ) and cell clumps larger than $10 \mu \mathrm{m} 2$ (symbol) 

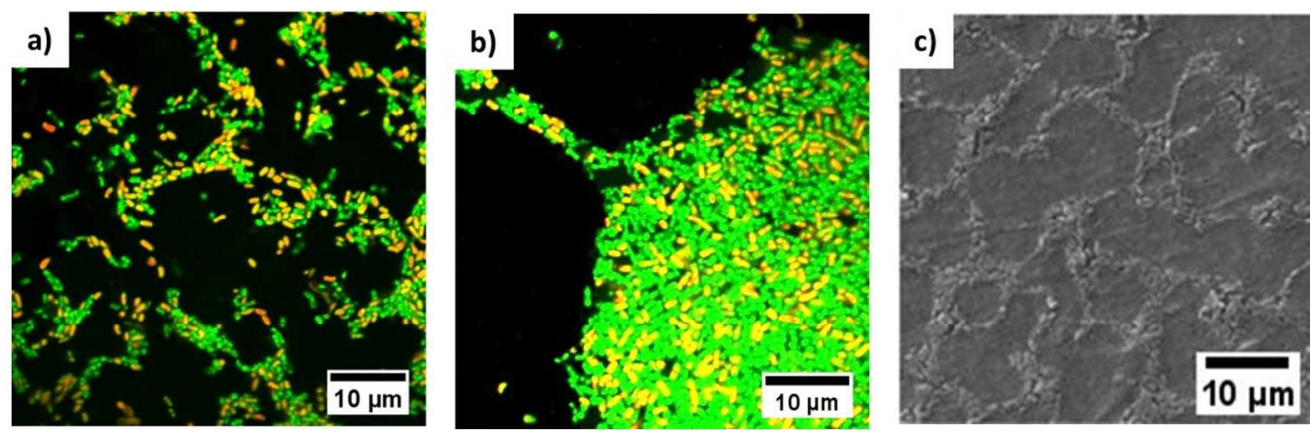

Figure 9. a) Circular pattern ring structure formed by bacteria after plasma treatment, b) Compact structure formed by bacteria after plasma treatment, c) Redrawn pattern rings formed by surface-deposited bacteria after plasma treatment observed by Bayliss et al[29]

$309 \times 99 \mathrm{~mm}(110 \times 110 \mathrm{DPI})$ 

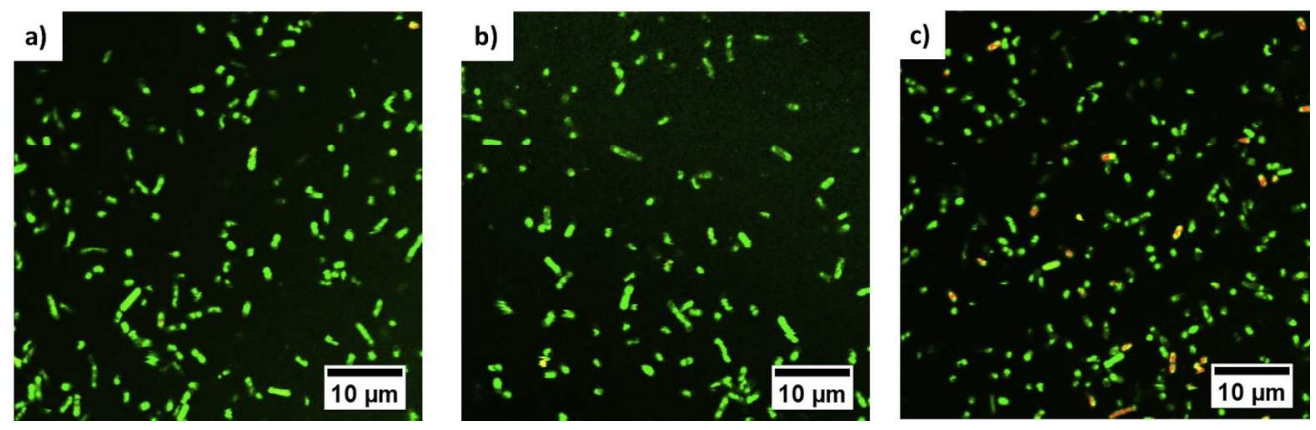

Figure 10. The drying effect on structure of biofilm by oven at $50^{\circ} \mathrm{C}$ for different treatment time. a) treated for $30 \mathrm{~s}, \mathrm{~b}$ ) treated for $60 \mathrm{~s}, \mathrm{c}$ ) treated for $90 \mathrm{~s}$

$254 \times 80 \mathrm{~mm}(300 \times 300 \mathrm{DPI})$ 